\title{
Development of Dietary Fiber Fortified Carrot (Daucus carota sativus) Ready to Serve Beverage
}

\author{
S. Jesupriya Poornakala ${ }^{1 *}$, N. Surya ${ }^{2}$ and K. Shanthi ${ }^{3}$ \\ ${ }^{1}$ Krishi Vigyan Kendra, Tamil Nadu Agricultural University, Pudukkottai, Tamil Nadu, India \\ ${ }^{2}$ Family Resource Management and Consumer Science, \\ Community Science College and Research Institute, Tamil Nadu Agricultural University, \\ Madurai, Tamil Nadu, India \\ ${ }^{3}$ Department of Food Science and Nutrition, Community Science College and Research \\ Institute, Tamil Nadu Agricultural University, Madurai, Tamil Nadu, India, India \\ *Corresponding author
}

\section{A B S T R A C T}

\begin{tabular}{l} 
K e y w o r d s \\
$\begin{array}{l}\text { Dietary fiber, } \\
\text { Carrot, } \\
\text { Beverage, Ready to } \\
\text { Serve }\end{array}$ \\
Article Info \\
$\begin{array}{l}\text { Accepted: } \\
\text { 26 September } 2020 \\
\text { Available Online: } \\
\text { 10 October } 2020\end{array}$ \\
\hline
\end{tabular}

Vegetables play a significant role in human nutrition, especially as sources of vitamins, minerals, dietary fiber and phytochemicals. Vegetable consumption is also rising, reflecting the consumer's desire for diversity, and awareness of nutritional benefits. The promotion of healthy vegetable products has coincided with a surging consumer interested in the healthy functionality of food. The fraction of vegetable residues that remains after juice processing contains plenty of bioactive compounds. Hence the present investigation was carried out to standardize carrot residue fortification as dietary fiber into carrot Ready to Serve (RTS) beverages. Dietary fiber was extracted from the carrot residues after juice extraction. The carrot RTS beverages were fortified with different concentration levels $(0.5 \%, 1 \%$ and $3 \%)$ of dietary fiber with the aim of increasing the dietary fiber intake. The physico-chemical characteristics such as $\mathrm{pH}$, total soluble solids, acidity, ascorbic acid, total sugar, reducing sugar and total dietary fiber were analyzed in carrot juices and organoleptically evaluated to assess the maximum acceptability of the products. Juice characteristics such as clarity, turbidity, non- enzymatic browning and color were analyzed. RTS beverage fortified with 0.5 per cent dietary fiber was found to be best in their sensory characteristics and physical properties. The standardized RTS beverages were packed in glass bottles and PET bottles and stored under refrigeration and storage studies performed.

\section{Introduction}

There is an increasing awareness among the general public of the advantages of diets rich in vegetables to ensure an adequate intake of most vitamins and micronutrients, dietary fibers, and phytochemicals that promote health. Vegetables, fruits and legume seeds provide carbohydrates, proteins, minerals and vitamins to our body. Besides these, they are 
also source of health promoting biologically active compounds (Ezekiel, 2013; Singh, 2017). Usually fruits are processed into juice, beverage, squash and syrups. However byproducts can be used as functional food ingredients such as phytochemicals, pharmaceuticals, food products, essential oils, seed oil, pectin and dietary fibers (Azad, 2014). Therefore, fruits by-products not only good source of bioactive compounds but also could be used as several value-added products (Noor et al., 2014). Phenolic compounds, including their subcategory Flavonoids, Anthocyanins, Catechins, Glucosinolates, Isoflavones, Lignans, phenolic acids are exhibit altogether plants. These compounds have the capacity to scavenge free radicals and show synergistic effects contributing to anti-inflammatory, antimicrobial, antimutagenic, anti-tumour and neuroprotective properties (Kang, 2011; Fujita, 2013). Carrot (Daucus carota Sativus) is one of the most important seasonal root vegetable of Apiaceae (Umbelliferae) family, grown extensively in India during winter season. It is an excellent source of $\beta$-carotene, a precursor of vitamin A, which protects cells from free radicals which may damage the basic cell structure of healthy cells (Demir et al., 2004).

Dias (2014) reported that carrot is a root vegetable with carotenoids, flavonoids, polyacetylenes, vitamins and minerals, all of which possess numerous nutritional and health benefits. Besides lending truth that carrots are good for eyes, carotenoids, polyphenols and vitamins present in carrot act as antioxidants, anticarcinogen and immune enhancers. Anti-diabetic, cholesterol and cardiovascular disease lowering, antihypertensive, hepatoprotective, renoprotective, and wound healing benefits of carrot have also been reported. The cardioand hepatoprotective, anti-bacterial, antifungal, anti-inflammatory, and analgesic effects of carrot seed extracts. Potter et al.,
(2011) reported that drinking carrot juice may protect that cardio vascular system by increasing total antioxtidant status and by decreasing lipid peroxidation independent of any of the cardiovasucular risk markers, Creactive protein, insulin, leptin, interleukin1a, body fat percentage, body mass index (BMI), blood pressure, antioxidant status, and malondialdehyde production measured in the study.

The concentrations of phenolics and other phytochemicals present in the peels, pulp/pomace and seeds of many fruits and vegetables are generally substantially higher than in their respective edible tissues, suggesting these wastes and residues to be the potential sources of bio-active compounds. These compounds are involved in the prevention and/or control of chronic disorders such as cancer and cardiovascular diseases.

The exponential growth of plant waste production from the agrofood industry is a critical global issue, considering its storage, disposal, environmental impact, and potential health risks. However, the exploitation of plant wastes/by-products for the recovery of added-value compounds offers new avenue for industrial growth and waste management (Attanzio et al., 2018). It is unquestionable that fruit juices, due to the content of vitamins, polyphenols, minerals, and other valuable nutrients, are beneficial to human health (Markowski et al., 2015). However, according to Oszmiański et al., (2007), health benefits are expected mainly in the case of cloudy juice consumption. On the other hand, irrespective of the form (clear or cloudy), fruit juices have a similar energy density and sugar content to sugar sweetened beverages. Hence the present study was carried out to determine the feasibility of fortification of dietary fiber on the production of healthy carrot RTS beverage. 


\section{Materials and Methods}

\section{Extraction of dietary fiber}

Dietary fiber from carrot residue was extracted using the method (Yoshimoto et al., 2005) with little modification. Carrot residues after juice extraction were mixed with water (1: $20 \mathrm{w} / \mathrm{v}$ ratio). An alpha-amylase was added $(0.1 \mathrm{ml} / \mathrm{g}$ sample $)$ to the residue. The sample was incubated at $95^{\circ} \mathrm{C}$ for $30 \mathrm{~min}$. After cooling down to $60^{\circ} \mathrm{C}$, an amyloglucosidase solution was added $(0.1 \mathrm{ml} /$ g sample) and incubated at $60^{\circ} \mathrm{C}$ for $30 \mathrm{~min}$. Finally, the mixture was filtered through Whatman No.4 filter paper and dried in the hot air oven at $50^{\circ} \mathrm{C}$. The dried samples were then powdered in mill using a $1 \mathrm{~mm}$ sieve.

\section{Development of carrot RTS fortified with dietary fiber}

Carrot RTS beverage was prepared as per FSSAI specification. Carrot RTS beverage was fortified with dietary fiber in different concentration levels with the aim of increasing the consumption of dietary fiber. The selected carrots were washed thoroughly in clean water. After washing and peeling, they were cut into pieces. Blanching process was carried out for carrots at the temperature of $100^{\circ} \mathrm{C}$ for 5 minutes. Pulping of the fruits was done with the help of mixer and the pulp was filtered through the muslin cloth to separate the residues. Sugar syrup was made with $13^{\circ}$ Brix and citric acid was added. Then the sugar syrup was added to the filtered pulp after cooling. The dietary fiber extracted from carrot residues was fortified each at 0.5 per cent $\left(T_{1}\right), 1.0$ per cent $\left(T_{2}\right)$ and 3.0 per cent $\left(T_{3}\right)$ levels in carrot RTS beverages. Carrot RTS beverage prepared without fortification of dietary fiber was considered as control $\left(\mathrm{T}_{0}\right)$. The prepared RTS beverage was poured immediately in sterilized glass and PET bottles leaving a head space of $3.0 \mathrm{~cm}$ and the bottles were corked with sterilized crown corks. The bottled RTS was pasteurized at a temperature of $90^{\circ} \mathrm{C}$ for 25 minutes and cooled to room temperature. RTS bottles were labeled and stored at refrigerated condition $\left(4^{\circ} \mathrm{C}\right)$.

\section{Physico-chemical analysis}

Protein was analyzed by the amount of nitrogen available in the sample by Micro Kjeldahl method (Ma and Zuazaga, 1942). The $\mathrm{pH}$ and acidity of the samples was estimated by the standard method (Saini et al., 2000). The total soluble solids of the samples were observed by using a hand refractometer $\left(0^{\circ}\right.$ to $32^{\circ}$ Brix) (Ranganna, 1986). The reducing and total sugar content of the samples was determined by Shaffer Somogyi micro method (McDonald and Foley, 1960).

\section{Sensory evaluation}

The quality attributes in terms of color and appearance, flavor, taste and overall acceptability were evaluated by a panel of 20 semi trained judges using a score card with 9 point hedonic rating scale (Amerine, 1965).

\section{Analysis of juice characteristics}

\section{Clarity}

Clarity is ascribed to particles in the juice, such as cellulose, hemicellulose, proteins, lipids and some other minor particles (Baker and Cameron, 1999). For fruit juices, stability of the clarity value is a visual quality factor associated with the flavor and color and is interconnected to consumer acceptance (Beveridge, 2002). The clarity was determined by measuring the absorbance at $660 \mathrm{~nm}$ using a 2201UV-Visible Double Beam Recording Spectrophotometer (Akesowan and Choonhahirun, 2013). 


\section{Turbidity}

Turbidity mainly occurs due to polysaccharides such as starch, pectin, cellulose, and hemicellulose (Nagar et al., 2012). The developed RTS beverages were subjected to turbidity measurements using a 2201UV-Visible Double Beam Recording Spectrophotometer (Systronics, India) with absorbance at $600 \mathrm{~nm}$ (Candrawinata, 2012).

\section{Non-enzymatic browning}

Non-enzymatic browning is one of the most important chemical reactions responsible for quality and color changes during the heating or prolonged storage of fruit juice (Arena $e t$ al., 2001). The increase in absorbance of a sample extract at $440 \mathrm{~nm}$ was taken as a measure of non enzymatic browning (Ranganna, 1995). Color is crucial characteristic in food as consumer preference of acceptability. Measurement of color was done using Hunter $L^{*} a^{*} b^{*}$ color scale Chromometer, Lovibond.

\section{Microbiological enumeration}

The microbial load of the stored samples was enumerated by dilution plate method (Istawankiss, 1984). The media used for bacteria was nutrient agar media, for moulds and fungi Martin's rose bengal agar and for yeast, yeast extract malt extract agar medium.

\section{Storage studies}

The carrot RTS beverage with best dietary fiber fortification level on the basis of sensory evaluation were packed in glass bottles and PET bottles and kept at refrigerated temperature and changes in sensory, physicochemical characteristics and microbial load were assessed during storage at 15 days intervals up to 45 days.

\section{Statistical analysis}

The data obtained were subjected to statistical analysis to find out the impact of treatments, storage periods and packaging materials on the quality of the samples during storage. Completely Randomized Design (FRBD) was applied for the analysis (Gomez and Gomez, 1984).

\section{Results and Discussion}

\section{Chemical constituents of dietary fiber extracted from carrot residues}

The dietary fiber yield was 21.6 per cent from carrot residue. The dietary fiber contained 5.3 per cent ash, 2.87 per cent protein, $\mathrm{pH} 5.0$ and 8.33 per cent moisture content.

\section{Sensory characteristics of the carrot RTS beverages}

The sensory characteristics of the freshly prepared carrot fortified RTS beverages with and without fortification of dietary fiber are given in Table 1. It was noticed that RTS beverage prepared with $0.5 \%$ fortification of dietary fiber $\left(T_{1}\right)$ obtained high sensory score in all quality attributes as scored by control sample $\left(\mathrm{T}_{0}\right)$ when compared to the other RTS beverages prepared with $1.0 \%\left(\mathrm{~T}_{2}\right)$ and $3.0 \%$ $\left(T_{3}\right)$ fortification of dietary fiber.

Hegenbart (1995) found that oat fibre can be incorporated into milk shakes, instant typebreakfast drinks, fruit and vegetable juices, ice tea, sports drinks, cappuccino and wine. Other beverages that can benefit from the addition of fibre include liquid diet beverages- both those created for people with special dietary needs as well as weight loss or meal replacement beverages. Larrauri et al., (1995) described the manufacture of powdered drink containing dietary fibre from pineapple peel. The product, contained 25\% dietary fibre. 
Physico - chemical characteristics of carrot RTS beverages

The $\mathrm{pH}$ of carrot RTS beverages ranged between 4.0 and 4.32 and acidity between 0.32 and 0.35 and TSS was $13^{\circ}$ brix for all the samples. The Ascorbic acid content was ranged from 35.60 to $35.90 \mathrm{mg}$ per cent, reducing sugar 2.95 to 3.30 per cent, total sugar 4.60 to 4.73 per cent. The total dietary fiber content ranged from 1.4 to 8.6 per cent (Table 2). Grigelmo-Miguel (1999) reported that by-products from orange juice extraction also have a high potential as dietary fiber sources.

\section{Juice characteristics of dietary fiber fortified carrot RTS beverages}

The physical properties such as clarity, turbidity and non enzymatic browning in carrot RTS beverages are given in Table 3 . The clarity values of carrot RTS beverages ranged from 0.063 to 0.195 in $\mathrm{T}_{0}, \mathrm{~T}_{1}, \mathrm{~T}_{2}$ and $\mathrm{T}_{3}$ samples. According to Sanz et al., (2008) asparagus fibers diminished the clarity and imparted a yellow-greenish color to the yogurt. The turbidity values of carrot RTS beverages were ranged between 0.123 to 0.190 for $\mathrm{T}_{0}, \mathrm{~T}_{1}, \mathrm{~T}_{2}$ and $\mathrm{T}_{3}$ samples. Turbidity of dietary fiber fortified RTS samples were reported to be more than the control RTS sample.

Thongsombat et al., (2007) found that the greater the amounts of crude pectin were added, the less the perceived scores in almost all attributes were observed in dietary fiber fortified guava juice. Therefore, the amount of $0.25 \%$ crude pectin was selected for subsequent guava juice processing. As compared to the control, the results pointed out that guava juice fortified with $0.25 \%$ crude pectin was not significantly different $(p>0.05)$ in the observed perceived scores of sensory attributes including color, flavor, mouth feel and overall acceptability whereas the perceived scores in turbidity and odor attributes were less significantly different $(p<0.05)$ than those of the control.

The non- enzymatic browning of carrot RTS beverages was $0.042,0.052,0.060$ and 0.071 for $\mathrm{T}_{0}, \mathrm{~T}_{1}, \mathrm{~T}_{2}$ and $\mathrm{T}_{3}$ samples respectively. It was recorded that control RTS beverage sample $\left(\mathrm{T}_{0}\right)$ developed low level of non enzymatic browning ( 0.042 OD) followed by RTS prepared with $0.5 \%$ fortification of dietary fiber $\left(\mathrm{T}_{1}\right)$ (0.052 OD). Bharate and Bharate (2014) also stated that non-enzymatic browning is one of the most important chemical reactions responsible for quality and color changes during the heating or prolonged storage of citrus juices.

\section{Colour value of dietary fiber fortified carrot RTS beverages}

Table 4 summarizes the color values of RTS beverages. Carrot RTS obtained 158.80, $167.09,169.84$ and 171.95 of $\left(\mathrm{L}^{*}\right)$ values, $78.05,88.65,89.34$ and 90.45 of $\mathrm{a}^{*}$ values and 102.10, 121.64, 124.92 and 126.03 of $\mathrm{b}^{*}$ values for $\mathrm{T}_{0}, \mathrm{~T}_{1}, \mathrm{~T}_{2}$ and $\mathrm{T}_{3}$ samples respectively. Low $\left(\mathrm{L}^{*}\right)$ values indicated that fortification of dietary fiber into the carrot RTS samples $\left(T_{1}, T_{2}\right.$ and $\left.T_{3}\right)$ affected the color properties of $\mathrm{L}^{*}$ values. $\mathrm{T}_{3}$ samples had darker colour than other samples. Sarac and Dogan (2016) also found that content and type of the fruit and vegetable dietary fiber concentrate in the butter model changed the hardness and the spreadability rating as textural properties and the same effects also were observed in color parameters and sensory evaluation.

\section{Storage studies}

The RTS beverage with best fortification level $(0.5 \%$ ) (on the basis of sensory evaluation) was packed in glass bottles and PET bottles and kept at refrigerated 
temperature and changes in sensory characteristics, physical and chemical characteristics were determined during storage at 15 days intervals up to 45 days.

\section{Changes in the sensory characteristics of} the dietary fiber fortified carrot RTS beverages during storage

The sensory characteristics of dietary fiber fortified carrot RTS beverages during storage are showed in Table 5. It depicts the sensory characteristics based on the mean scores for all the quality attributes (color and appearance, flavor, taste and overall acceptability) of the samples stored at refrigeration temperature. At the end of storage period both the samples $\left(T_{0}\right.$ and $\left.T_{1}\right)$ packed in both the packaging materials $\left(\mathrm{P}_{1}\right.$ and $\mathrm{P}_{2}$ ) remained under the consideration of "Like moderately" by panel members. RTS beverage packed in PET bottle obtained lowest scores than glass bottle. Rashid et al., (2018) also reported that the overall acceptability of guava RTS was decreased from 8.32 to 5.30 . It may be due to nonenzymatic reactions like caramelization and Millard.

Physico-chemical characteristics of carrot RTS beverages fortified with dietary fiber during storage

The pH, TSS and acidity of the carrot RTS beverages fortified with dietary fiber during storage is given in Table 6 .

\section{pH}

Carrot RTS beverages had an initial $\mathrm{pH}$ of 4.0 in $\mathrm{T}_{0}$ and 4.20 in $\mathrm{T}_{1}$. During storage the $\mathrm{pH}$ of the RTS beverages increased to 3.61 and 3.66 in $\mathrm{T}_{0}$ and $\mathrm{T}_{1}$ samples stored in glass bottles, 4.26 and 4.36 in $T_{0}$ and $T_{2}$ samples in PET bottles respectively.

\section{Total Soluble Solids}

It was found that the TSS content of the carrot RTS beverages was significantly increased during the storage period. The initial TSS was $13.0^{\circ} \mathrm{Bx}$ in all beverages. The values of carrot RTS beverages were increased to 13.36 in $\mathrm{T}_{0}$ and 13.29 in $\mathrm{T}_{1}$ samples, which were stored in glass bottles and the values increased to 13.37 in $\mathrm{T}_{0}$ and 13.35 in $\mathrm{T}_{1}$ which were stored in PET bottles.

\section{Acidity}

The acidity of carrot RTS beverages was 0.33 and 0.35 per cent in $T_{0}$ and $T_{1}$ respectively. After storage of forty five days the acidity was significantly decreased to $0.20\left(\mathrm{~T}_{0}\right)$ and $0.24\left(\mathrm{~T}_{1}\right)$ per cent in both the glass bottled $\left(\mathrm{P}_{1}\right)$ samples and in PET bottled $\left(\mathrm{P}_{2}\right)$ samples.

Similar results were reported by Dambalkar et al., (2015) that the acidity and TSS of beetroot, orange and ginger RTS were increased while, $\mathrm{pH}$ and ascorbic acid of beverage decreased progressively during storage at refrigerated temperature over a period of 90 days. This may be due to the excessive fermentation and presence of lactic acid reducing micro-organism.

\section{Changes in the chemical characteristics carrot RTS beverages during storage}

The ascorbic acid, reducing sugar, total sugar and dietary fiber of the carrot RTS beverages fortified with dietary fiber during storage is given in Table 7.

\section{Ascorbic acid}

The initial ascorbic acid content was found to be 35.68 and $35.89 \mathrm{mg} / 100 \mathrm{ml}$ in $\mathrm{T}_{0}$ and $\mathrm{T}_{1}$ samples stored in glass and PET bottles respectively. At the end of forty five days of storage, the ascorbic acid content of carrot 
RTS beverages was significantly reduced to 33.26 for $\mathrm{T}_{0}$ and $34.45 \mathrm{mg} / 100 \mathrm{ml}$ for $\mathrm{T}_{0}$ and $\mathrm{T}_{1}$ in glass bottled samples and 33.24 for $\mathrm{T}_{0}$ and $33.44 \mathrm{mg} / 100 \mathrm{ml}$ for $\mathrm{T}_{1}$ in PET bottled samples respectively.

\section{Reducing sugar}

The initial reducing sugar content was 3.30 for $\mathrm{T}_{0}$ and 3.11 for $\mathrm{T}_{0}$ and $\mathrm{T}_{1}$ of carrot RTS beverages respectively. At the end of the forty five days of storage the reducing sugar content was significantly increased to 3.46 for $\mathrm{T}_{0}$ and 3.31 for $\mathrm{T}_{1}$ glass bottled samples, and
3.45 for $\mathrm{T}_{0}$ and 3.30 for $\mathrm{T}_{1}$ PET bottled samples of carrot respectively.

\section{Total sugar}

The initial total sugar contents of the RTS beverages was 4.73 per cent in $\mathrm{T}_{0}$ samples and 4.61 per cent in $\mathrm{T}_{1}$ samples of carrot RTS respectively. At the end of the forty five days of storage the total sugar content was significantly increased to 4.95 in $\mathrm{T}_{0}$ and 4.74 in $\mathrm{T}_{1}$ glass bottled samples, and 4.96 in $\mathrm{T}_{0}$ and 4.97 in $T_{1}$ in PET bottled samples of carrot RTS respectively.

Table.1 Sensory characteristics (mean scores) of the dietary fiber fortified carrot RTS beverages

\begin{tabular}{|c|c|c|c|c|}
\hline Treatment & $\begin{array}{c}\text { Color and } \\
\text { appearance }\end{array}$ & Flavor & Taste & $\begin{array}{c}\text { Overall } \\
\text { acceptability }\end{array}$ \\
\hline $\mathbf{T}_{\mathbf{0}}$ & 9.0 & 9.0 & 9.0 & 9.0 \\
\hline $\mathbf{T}_{\mathbf{1}}$ & 9.0 & 9.0 & 9.0 & 8.5 \\
\hline $\mathbf{T}_{\mathbf{2}}$ & 9.0 & 8.5 & 8.5 & 8.0 \\
\hline $\mathbf{T}_{\mathbf{3}}$ & 8.0 & 8.0 & 8.0 & 7.5 \\
\hline
\end{tabular}

$\mathrm{T}_{0}$-Control; $\mathrm{T}_{1^{-}}$carrot RTS $+0.5 \%$ dietary fiber; $\mathrm{T}_{2}$ - carrot RTS $+0.5 \%$ dietary fiber; $\mathrm{T}_{3}$ - carrot RTS $+0.5 \%$ dietary fiber

Table.2 Physico -chemical characteristics of dietary fiber fortified carrot RTS

\begin{tabular}{|c|l|c|c|c|c|}
\hline S.No. & \multicolumn{1}{|c|}{ Characteristics } & $\mathbf{T}_{\mathbf{0}}$ & $\mathbf{T}_{\mathbf{1}}$ & $\mathbf{T}_{\mathbf{2}}$ & $\mathbf{T}_{\mathbf{3}}$ \\
\hline $\mathbf{1 .}$ & $\mathrm{pH}$ & 4.0 & 4.2 & 4.2 & 4.32 \\
\hline $\mathbf{2 .}$ & Acidity & 0.33 & 0.35 & 0.32 & 0.33 \\
\hline $\mathbf{3 .}$ & TSS $\left({ }^{0} \mathrm{Bx}\right)$ & 13.0 & 13.0 & 13.0 & 13.0 \\
\hline $\mathbf{4 .}$ & Ascorbic acid & 35.68 & 35.85 & 35.90 & 35.60 \\
\hline & (mg/100ml) & & & & \\
\hline $\mathbf{5 .}$ & Reducing Sugar $(\%)$ & 3.30 & 3.11 & 3.07 & 2.95 \\
\hline 6. & Total sugar (\%) & 4.73 & 4.60 & 4.70 & 4.72 \\
\hline 7. & Total dietary fiber $(\%)$ & 1.40 & 3.05 & 4.98 & 8.60 \\
\hline
\end{tabular}

$\mathrm{T}_{0}$-Control; $\mathrm{T}_{1^{-}}$Carrot RTS $+0.5 \%$ dietary fiber; $\mathrm{T}_{2^{-}}$Carrot RTS $+0.5 \%$ dietary fiber; $\mathrm{T}_{3^{-}}$Carrot RTS $+0.5 \%$ dietary fiber 
Table.3 Juice characteristics of dietary fiber fortified carrot RTS beverages

\begin{tabular}{|c|c|c|c|}
\hline Treatment & $\begin{array}{c}\text { Clarity } \\
\text { (OD Value) }\end{array}$ & $\begin{array}{c}\text { Turbidity } \\
\text { (OD Value) }\end{array}$ & $\begin{array}{c}\text { NEB } \\
\text { (OD Value) }\end{array}$ \\
\hline $\mathbf{T}_{\mathbf{0}}$ & 0.063 & 0.123 & 0.042 \\
\hline $\mathbf{T}_{\mathbf{1}}$ & 0.173 & 0.131 & 0.052 \\
\hline $\mathbf{T}_{\mathbf{2}}$ & 0.180 & 0.142 & 0.060 \\
\hline $\mathbf{T}_{\mathbf{3}}$ & 0.195 & 0.190 & 0.071 \\
\hline
\end{tabular}

$\mathrm{T}_{0}$-Control; $\mathrm{T}_{1}$ - Carrot RTS $+0.5 \%$ dietary fiber; $\mathrm{T}_{2}$ - Carrot RTS +0.5\% dietary fiber; $\mathrm{T}_{3^{-}}$Carrot RTS +0.5\% dietary fiber, OD - Optical Density

Table.4 Colour value of dietary fiber fortified carrot RTS beverages

\begin{tabular}{|c|c|c|c|}
\hline \multirow[t]{2}{*}{ Treatment } & \multirow[t]{2}{*}{ Lightness $\left(\mathrm{L}^{*}\right)$} & \multicolumn{2}{|c|}{ Chromatically coordinates } \\
\hline & & $\mathbf{a}^{*}($ red $(+\mathbf{a})$ to greenness $(-\mathbf{a}))$ & $b^{*}($ yellow $(+b)$ to blueness (-b)) \\
\hline $\mathbf{T}_{\mathbf{0}}$ & 158.80 & 78.05 & 102.10 \\
\hline $\mathbf{T}_{1}$ & 167.09 & 88.65 & 121.64 \\
\hline $\mathbf{T}_{2}$ & 169.84 & 89.34 & 124.92 \\
\hline $\mathbf{T}_{\mathbf{3}}$ & 171.95 & 90.45 & 126.03 \\
\hline
\end{tabular}

$\mathrm{T}_{0}$-Control; $\mathrm{T}_{1^{-}}$Carrot RTS $+0.5 \%$ dietary fiber; $\mathrm{T}_{2}$ - Carrot RTS $+0.5 \%$ dietary fiber; $\mathrm{T}_{3}$ - Carrot RTS $+0.5 \%$ dietary fiber

Table.5 Changes in the sensory characteristics of carrot RTS beverages during storage

\begin{tabular}{|c|c|c|c|c|}
\hline \multirow[t]{2}{*}{ Quality attributes } & \multicolumn{2}{|c|}{$\mathbf{P}_{1}$} & \multicolumn{2}{|c|}{$\mathbf{P}_{2}$} \\
\hline & $\mathbf{T}_{0}$ & $T_{1}$ & $\mathbf{T}_{\mathbf{0}}$ & $T_{1}$ \\
\hline \multicolumn{5}{|l|}{ Storage period (days) } \\
\hline \multicolumn{5}{|c|}{ Color and appearance } \\
\hline Initial day & 9.0 & 9.0 & 9.0 & 9.0 \\
\hline 45 & 7.9 & 7.7 & 7.5 & 7.5 \\
\hline \multicolumn{5}{|c|}{ Flavor } \\
\hline Initial day & 8.9 & 8.9 & 8.9 & 8.9 \\
\hline 45 & 7.7 & 7.5 & 7.5 & 7.5 \\
\hline \multicolumn{5}{|c|}{ Taste } \\
\hline Initial day & 9.0 & 9.0 & 9.0 & 9.0 \\
\hline 45 & 7.5 & 7.4 & 7.5 & 7.5 \\
\hline \multicolumn{5}{|c|}{ Overall acceptability } \\
\hline Initial day & 8.9 & 8.6 & 8.9 & 8.6 \\
\hline 45 & 7.7 & 7.5 & 7.5 & 7.4 \\
\hline
\end{tabular}

$\mathrm{P}_{1}-$ Glass bottle, $\mathrm{P}_{2}-$ PET bottle, $\mathrm{T}_{0}-$ Control, $\mathrm{T}_{1}$ - RTS $+0.5 \%$ dietary fiber 
Table.6 The pH, TSS and acidity of the carrot RTS beverages fortified with dietary fiber during storage

\begin{tabular}{|c|c|c|c|c|c|c|c|}
\hline \multirow{2}{*}{$\begin{array}{l}\text { Packaging } \\
\text { material }\end{array}$} & \multirow{2}{*}{$\begin{array}{l}\text { Storage } \\
\text { period } \\
\text { (Days) }\end{array}$} & \multicolumn{2}{|l|}{ pH } & \multicolumn{2}{|c|}{ TSS $\left({ }^{0}\right.$ Brix $)$} & \multicolumn{2}{|c|}{ Acidity (per cent) } \\
\hline & & $\mathbf{T}_{\mathbf{0}}$ & $\mathbf{T}_{1}$ & $\mathbf{T}_{\mathbf{0}}$ & $T_{1}$ & $\mathbf{T}_{\mathbf{0}}$ & $\mathbf{T}_{1}$ \\
\hline \multirow[t]{4}{*}{$\mathbf{P}_{1}$} & 0 & 4.00 & 4.20 & 13.00 & 13.00 & 0.33 & 0.35 \\
\hline & 15 & 4.16 & 4.26 & 13.16 & 13.13 & 0.29 & 0.31 \\
\hline & 30 & 4.21 & 4.31 & 13.25 & 13.24 & 0.24 & 0.29 \\
\hline & 45 & 4.26 & 4.36 & 13.36 & 13.29 & 0.20 & 0.24 \\
\hline \multirow[t]{4}{*}{$\mathbf{P}_{2}$} & 0 & 4.00 & 4.20 & 13.00 & 13.00 & 0.33 & 0.35 \\
\hline & 15 & 4.15 & 4.26 & 13.17 & 13.14 & 0.29 & 0.31 \\
\hline & 30 & 4.21 & 4.31 & 13.28 & 13.24 & 0.24 & 0.28 \\
\hline & 45 & 4.26 & 4.36 & 13.37 & 13.35 & 0.20 & 0.24 \\
\hline $\begin{array}{l}\text { CD at } \\
0.05 \%\end{array}$ & & \multicolumn{2}{|c|}{$\begin{array}{l}\text { T- } 0.014^{*} ; \mathrm{P}-0.014^{* *} ; \\
\text { S- } 0.019 \mathrm{NS} ; \mathrm{TPS}- \\
0.039 \mathrm{NS}\end{array}$} & \multicolumn{2}{|c|}{$\begin{array}{l}\text { T- } 0.010^{* *} ; \text { P- } 0.010^{*} ; \\
\text { S- } 0.014^{* *} ; \text { TPS - } \\
0.025^{* *}\end{array}$} & \multicolumn{2}{|c|}{$\begin{array}{l}\text { T- } 0.009^{*} ; \text { P- } 0.013^{*} ; \\
\text { S- } 0.013^{* *} ; \text { TPS - } \\
0.027 N S\end{array}$} \\
\hline
\end{tabular}

$\mathrm{T}_{0}$-Control; $\mathrm{T}_{1}$ - Carrot RTS $+0.5 \%$ dietary fiber; $\mathrm{T}_{2}$ - Carrot RTS $+0.5 \%$ dietary fiber; $\mathrm{T}_{3^{-}}$Carrot RTS $+0.5 \%$ dietary fiber

Table.7 Changes in the chemical characteristics carrot RTS beverages during storage

\begin{tabular}{|c|c|c|c|c|c|c|c|c|c|}
\hline \multirow[t]{2}{*}{$\begin{array}{l}\text { Packaging } \\
\text { material }\end{array}$} & \multirow[t]{2}{*}{$\begin{array}{l}\text { Storage } \\
\text { period } \\
\text { (Days) }\end{array}$} & \multicolumn{2}{|c|}{$\begin{array}{l}\text { Ascorbic acid (mg } \\
\% \text { ) } \\
\text { mg/ } 100 \mathrm{ml}\end{array}$} & \multicolumn{2}{|c|}{ Reducing sugar (\%) } & \multicolumn{2}{|c|}{ Total sugar (\%) } & \multicolumn{2}{|c|}{ Dietary fiber $(\%)$} \\
\hline & & $\mathbf{T}_{\mathbf{0}}$ & $\mathbf{T}_{1}$ & $\mathbf{T}_{\mathbf{0}}$ & $\mathbf{T}_{1}$ & $\mathbf{T}_{\mathbf{0}}$ & $\mathbf{T}_{1}$ & $\mathbf{T}_{\mathbf{0}}$ & $\mathbf{T}_{1}$ \\
\hline \multirow[t]{4}{*}{$\mathbf{P}_{1}$} & 0 & 35.68 & 35.89 & 3.30 & 3.11 & 4.73 & 4.61 & 1.40 & 3.05 \\
\hline & 15 & 34.45 & 35.45 & 3.39 & 3.18 & 4.79 & 4.64 & 1.40 & 3.08 \\
\hline & 30 & 33.86 & 34.98 & 3.42 & 3.25 & 4.86 & 4.69 & 1.50 & 3.08 \\
\hline & 45 & 33.26 & 34.45 & 3.46 & 3.31 & 4.95 & 4.74 & 1.50 & 3.10 \\
\hline \multirow[t]{4}{*}{$\mathbf{P}_{2}$} & 0 & 35.68 & 35.89 & 3.30 & 3.11 & 4.73 & 4.61 & 1.40 & 3.05 \\
\hline & 15 & 34.47 & 35.45 & 3.38 & 3.17 & 4.81 & 4.73 & 1.40 & 3.09 \\
\hline & 30 & 33.78 & 33.98 & 3.41 & 3.24 & 4.89 & 4.84 & 1.50 & 3.09 \\
\hline & 45 & 33.24 & 33.44 & 3.45 & 3.30 & 4.96 & 4.97 & 1.50 & 3.10 \\
\hline $\begin{array}{l}\text { CD at } \\
0.05 \%\end{array}$ & & \multicolumn{2}{|c|}{$\begin{array}{l}\text { T- } 0.168^{*} ; \text { P- } 0.168^{* *} \text {; } \\
\text { S- } 0.238^{* *} ; \text { TPS - } \\
0.476^{*}\end{array}$} & \multicolumn{2}{|c|}{$\begin{array}{l}\text { T- } 0.006^{* *} ; \text { P- } 0.006^{* *} ; \\
\text { S- } 0.008^{* *} ; \text { TPS - } \\
0.017^{* *}\end{array}$} & \multicolumn{2}{|c|}{$\begin{array}{l}\text { T- } 0.005^{* *} ; \text { P- } 0.005^{* *} ; \\
\text { S- } 0.008^{* *} ; \text { TPS }- \\
0.016 \mathrm{NS}\end{array}$} & \multicolumn{2}{|c|}{$\begin{array}{l}\text { T- } 0.091^{* *} ; \text { P- } 0.091^{* *} \\
\text { S- 0.091**; TPS - } \\
0.183 \text { NS }\end{array}$} \\
\hline
\end{tabular}

$\mathrm{T}_{0}$-Control; $\mathrm{T}_{1^{-}}$Carrot RTS $+0.5 \%$ dietary fiber; $\mathrm{T}_{1}$ - Carrot RTS $+0.5 \%$ dietary fiber; $\mathrm{T}_{1^{-}}$Carrot RTS $+0.5 \%$ dietary fiber 
Table.8 Changes in the microbial population of carrot RTS beverages during storage

\begin{tabular}{|c|c|c|c|c|c|c|c|}
\hline \multirow[t]{2}{*}{$\begin{array}{c}\text { Packaging } \\
\text { material }\end{array}$} & \multirow{2}{*}{$\begin{array}{c}\text { Storage } \\
\text { period } \\
\text { (Days) }\end{array}$} & \multicolumn{2}{|c|}{ Bacterial count $10^{5} \mathrm{CFU} / \mathrm{ml}$} & \multicolumn{2}{|c|}{ Fungal count $10^{4} \mathrm{CFU} / \mathrm{ml}$} & \multicolumn{2}{|c|}{$\begin{array}{c}\text { Yeast and mould count } 10^{3} \\
\text { CFU/ml }\end{array}$} \\
\hline & & $\mathbf{T}_{\mathbf{0}}$ & $\mathrm{T}_{1}$ & $\mathbf{T}_{\mathbf{0}}$ & $\mathbf{T}_{1}$ & $T_{0}$ & $\mathbf{T}_{1}$ \\
\hline \multirow[t]{2}{*}{$\mathbf{P}_{1}$} & Initial day & BDL & BDL & BDL & $\mathrm{BDL}$ & BDL & BDL \\
\hline & 45 & BDL & 0.22 & 0.33 & 0.66 & 1.33 & 1.66 \\
\hline \multirow[t]{2}{*}{$\mathbf{P}_{2}$} & Initial day & BDL & BDL & BDL & BDL & BDL & BDL \\
\hline & 45 & BDL & 0.22 & 0.33 & 0.66 & 1.33 & 1.66 \\
\hline
\end{tabular}

BDL - Below Detectable Level $\quad \mathrm{P}_{1}$ - Glass bottle $\quad \mathrm{P}_{2}$ - PET bottle $\mathrm{T}_{0}$-Control, $\mathrm{T}_{1}-\mathrm{RTS}+0.5 \%$ dietary fiber

\section{Total dietary fiber}

The initial total dietary fiber content was 1.4 in $\mathrm{T}_{0}$ and 3.05 in $\mathrm{T}_{1}$ samples of carrot $\mathrm{RTS}$ beverages respectively. At the end of the storage period the total dietary fiber content was 1.5 per cent in $T_{0}$ and 3.10 per cent in $T_{1}$ both the glass and in PET bottled samples of carrot RTS respectively. In case of beverages and drinks, the addition of dietary fibre increases their viscosity and stability, soluble fibre being the most used because it is more dispersible in water than insoluble fibre. Some examples of soluble fibres are those from fractions of grains and multi-fruits (Bollinger, 2001), pectins (Bjerrum, 1996), $\beta$ glucans, cellulose beet-root fibre (Nelson, 2001).

Similar observations were made by Khayum et al., (2018) that the total sugars and reducing sugars of the jamun RTS blended with avocado and nannari were found to have increased during the storage whereas ascorbic acid content had decreased.

\section{Changes in the microbial population of dietary fiber fortified carrot RTS beverages during storage}

Initially, there was no microbial count in the prepared carrot RTS beverage samples. At the end of storage period carrot RTS $\mathrm{T}_{0}$ sample indicated as below detectable level but it was increased in $\mathrm{T}_{1}$ sample to $0.22 \times 10^{5} \mathrm{cfu} / \mathrm{ml}$ in both glass and PET bottled samples respectively.

The fungal count of was increased to $0.33 \times$ $10^{4} \mathrm{cfu} / \mathrm{ml}$ in $\mathrm{T}_{0}$ and $0.6610^{4} \mathrm{cfu} / \mathrm{ml}$ in $\mathrm{T}_{1}$ samples stored in both the glass bottles and PET bottles respectively. The yeast and mould count was increased to $1.33 \times 10^{4}$ $\mathrm{cfu} / \mathrm{ml}$ and $1.66 \times 10^{4} \mathrm{cfu} / \mathrm{ml}$ for $\mathrm{T}_{0}$ and $\mathrm{T}_{1}$ samples stored both in glass and PET bottles respectively. The increase in microbial load for 45 days of storage was negligible and safe for consumption.

Sindumathi and Premalatha (2013) concluded that initially there was no bacterial count in flavored papaya pineapple blended RTS beverage during storage. It had increased to $3.00 \times 10^{-6}$ after 120 days of storage. There was no fungal population was observed in flavored papaya pineapple blended RTS beverage. However, there was negligible growth of mold and yeast in the drinks.

In conclusion, the food industry is continuously looking for novel sources of dietary fiber to be utilized as a component in processed foods due to its abundant health properties associated to its consumption. Generally, dietary fiber is obtained from cereal and their by-products. In recent years, by-products produced from the fruit and vegetable industry have comparatively higher 
dietary fiber content with more bioactive compounds. Thus dietary fiber, obtained by the processing of fruit and vegetable byproducts, are appropriate for functional food product development. In the present investigation, dietary fiber extracted from carrot residues was fortified into carrot RTS beverages at three different concentration levels with the aim of improving the dietary fiber content. The formulated carrot RTS beverages contained more dietary fiber and ascorbic acid. Among the three treatments experimented, carrot RTS beverage formulated with $0.5 \%$ dietary fiber fortification was found to be highly acceptable based on the sensory characteristics and physical properties.

\section{References}

Amerine, M.A., Pangborn, R.M. and Roessler, E.B. 1965. Principles of sensory evaluation of food. In: Food Science and Technology Monographs. Academic Press. New York. Pp. 338339.

Akesowan, A. and Choonhahirun, A. 2013. Effect of enzyme treatment on guava juice production using response surface methodology. The J. Ani. Plant Sci., 23(1): 114-120.

Arena, E., Fallico, B. and E. Maccarone. 2001. Thermal damage in blood orange juice: kinetics of 5-hydroxymethyl-2furancarboxaldehyde formation. Int $\mathbf{J}$ Food Sci Technol., 36:145-151.

Attanzio, A., Tesoriere, L., Poojary, M.M. and Cilla, A. 2018. Fruit and Vegetable Derived Waste as a Sustainable Alternative Source of Nutraceutical Compounds. Journal of Food Quality 2018; $1-2$.

Azad, A. K. M., Ali, M. A., Akter, M. S., Rahman, M. J. and Ahmed, M. 2014. Isolation and characterization of pectin extracted from lemon pomace during ripening. Journal of Food and Nutrition Sciences. 2(2): 30-35.

Bharate, S.S. and Bharate, S.B.2014. Nonenzymatic browning in citrus juice: chemical markers, their detection and ways to improve product quality. J Food Sci Technol. 51(10): 2271-2288.

Bjerrum, K.S. 1996. New applications for pectins. Food Technol. 3:32- 34.

Bollinger, H. 2001. Functional drinks with dietary fibre. Fruit Process. 12:252-254.

Candrawinata, V.I., Blades, B. L., Golding, J. B., Stathopoulos, C. E. and Roach, P. D. 2012. Effect of clarification on the polyphenolic compound content and antioxidant activity of commercial apple juices. Int. J. Food Res., 19(3): 10551061.

Dambalkar, V. S., Rudrawar, B. D. and Poojari, V. R. 2015. Effect on PH, TSS, acidity, ascorbic acid and sensory attributes during storage period of RTS made from beetroot, orange and ginger juice. International Journal Of Food and Nutritional Sciences. 4 (5): 99-105.

Demir, N., Acar, J. and Bahceci, K.S. 2011. Effect of storage on quality of carrot juices produced with lacto fermentation and acidification. European Food Research and Technology 218(5):465468.

Dias, J.C.S. 2014. Nutritional and Health Benefits of Carrots and Their Seed Extracts. Food and Nutrition Sciences. 5, 2147-2156.

Ezekiel, R., Singh, N., Sharma, S. and Kaur, A, 2013. Beneficial phytochemicals in potato-a review. Food Research International, 50(2): 487-496.

Fujita, A., Borges, K., Correia, R., de Melo Franco, B. D. G. and Genovese, M. I.2013. Impact of spouted bed drying on bioactive compounds, antimicrobial and antioxid0.ant activities of commercial frozen pulp of camu-camu (Myrciaria dubia Mc. Vaugh). Food research 
international. 54(1), 495-500.

Grigelmo-Miguel, N. and Martín-Belloso, O. 1999. Comparison of dietary fibre from by-products of processing fruits and greens and from cereals. LWT - Food Science and Technology. 32, 503-508.

Gomez, K.A. and Gomez, A.A. 1984. Statistical procedures for agricultural research (2 ed.). John Wiley and sons, New York, 680p.

Hegenbart, S. 1995. Using fibres in beverages. Food Prod Des. 5 (3):68-78.

Istawankiss, 1984. Testing methods of food microbiology. Elsevier pub. Ltd., 395397.

Larrauri, J.A., Borroto, B., Perdomo, U. and Tabares, Y. 1995. Manufacture of a powdered drink containing dietary fibre: FIBRALAX. Alimentaria. 260:23-25.

Kang, N. J., Shin, S. H., Lee, H. J. and Lee, K. W. 2011. Polyphenols as small molecular inhibitors of signaling cascades in carcinogenesis. Pharmacology and therapeutics, 130(3): 310-324.

Khayum, A., Krishna1, H.C., Gowda, A.P.M., Sadananda, G.K. and Shankarappa, T.H. 2018. Formulation and Evaluation of Jamun RTS Blended with Avocado and Nannari - A Nutraceutical Drink. International Journal of Current Microbiology and Applied Sciences. 7(6): 535-542.

Ma, T. S and Zuazaga, G. 1942. MicroKjeldahl determination of nitrogen. A new indicator and an improved rapid method. Ind. Eng. Chem., (Analytical Edition). 14:280-2.

Markowski, J., Baron, A., LE Quéré., J.M. and Płocharski, W. 2015. Composition of clear and cloudy juices from French and Polish apples in relation to processing technology. LWT - Food Science and Technology. 62(1), 813820.

McDonald, E.J. and Foley, B. Y. 1960.
Development of bulgur-like product using extrusion cooking. J. Assoc. Offic. Agric. Chem., 43(2): 407-411.

Nagar, S., Mittal, A. and Gupta, V. K. 2012. Enzymatic clarification of fruit juices (apple, pineapple and tomato) using purified Bacillus pumilus SV-85S xylanase. Biotechnology and Bioprocess Engineering., 17: 11651175.

Nelson, A.L. 2001. High-fibre ingredients: Eagan Press Handbook Series. Eagan Press, St. Paul.

Noor, N., Sarfraz, R. A., Ali, S. and Shahid, M. 2014. Antitumour and antioxidant potential of some selected Pakistani honeys. Food Chemistry. 143: 362-366.

Oszmianski, J., Wolniak., M, Wojdyło, A. and Wawer, I. 2007. Comparative study of polyphenolic content and antiradical activity of cloudy and clear apple juices. Journal of the Science of Food and Agriculture.87 (4): 573 - 579.

Potter, A.S., Foroudi, S., Stamatikos, A., Patil, B.S. and Deyhim, F. 2011. Drinking carrot juice increases total antioxidant status and decreases lipid peroxidation in adults. Nutrition Journal. 10:96.

Ranganna,S.1986. Handbook of Analysis and Quality Control contents of Indian fruits. Journal of Food Composition and Analysis 16(6): 677- 687 for Fruit and Vegetable Products. Tata McGraw- Hill Publishing Company, New Delhi, India.124-125.

Ranganna, S. 1995. Manual of analysis of fruits and vegetables products, Tata McGraw Hill publishing Co., Ltd., New Delhi. 1-2, 7-11 and 13. Res. 4(2): 2319- 7064.

Rashid, R., Bhat, A., Dayal, A., Sood, M. and Sharma, S. 2018. Studies on storage stability of guava RTS The Pharma Innovation Journal. 7(5): 230-233. 
Saini, R S., Sharma, K. D., Dhankar, O. P. and R. A. Kaushik, 2000. Laboratory Manual Analytical Techniques in Horticulture. Agrobios Pub. Jodphur. India. 72.

Sanz,T., Salvador, A., JimÈnez, A. and Fiszman, S.M. J. 2008. European Food Res.Technol. 227(5): 1515-1521.

Saraç, M.G. and Dogan, M. 2016. Incorporation of dietary fiber concentrates from fruit and vegetable wastes in butter: effects on physicochemical, textural, and sensory properties. European Food Research and Technology. 242: 1331-1342.

Sindumathi, G1, Premalatha .M .R. 2015. Development and Storage Studies of Naturally Flavored Papaya-Pineapple Blended Ready-to-Serve (RTS) Beverages International Journal of
Science and Research. 4 (2): 856-860. Singh, R., Dhanani, T. and Kumar, S. 2017. Supercritical Fluid Extraction of Bioactive Compounds from Fruits and Vegetables. Fruit and Vegetable Phytochemicals: Chemistry and Human Health, 2nd Edition, 749-762.

Thongsombat, W., Sirichote, A. and Chanthachum, S. 2007. The production of guava juice fortified with dietary fiber Songklanakarin J. Sci. Technol. 29(Suppl.1): 187-196.

Yoshimoto, M.O., Yamakawa and H. Tanoue. 2005. Potential chemo preventive properties and varietal difference of dietary fiber from sweet potato (Ipomoea batatas L.) root. Japan Agricultural Research Quarterly. 39(1): $37-43$.

\section{How to cite this article:}

Jesupriya Poornakala, S., N. Surya and Shanthi, K. 2020. Development of Dietary Fiber Fortified Carrot (Daucus carota sativus) Ready to Serve Beverage. Int.J.Curr.Microbiol.App.Sci. 9(10): 3771-3783. doi: https://doi.org/10.20546/ijcmas.2020.910.434 